\title{
THE EFFECT OF FEEDING FREQUENCY ON THE FIN CONDITION IN RAINBOW TROUT (ONCORHYNCHUS MYKISS)
}

\author{
Ondřej Klíma ${ }^{1,3}$, Lukáš Kohút², Jan Mareš³, Radovan Kopp ${ }^{3}$
}

\begin{abstract}
${ }^{1}$ Moravian Fishing Association, r.a. branch association Nová Ves, Czech Republic
${ }^{2}$ Research Centre for Toxic Compounds in the Environment (RECETOX), Faculty of Science, Masaryk University, Czech Republic

${ }^{3}$ Department of Zoology, Fisheries, Hydrobiology and Apiculture, Faculty of AgriSciences, Mendel University in Brno, Czech Republic
\end{abstract}

\begin{abstract}
KLÍMA ONDŘEJ, KOHÚT LUKÁŠ, MAREŠ JAN, KOPP RADOVAN. 2018. The Effect of Feeding Frequency on the Fin Condition in Rainbow Trout (Oncorhynchus Mykiss). Acta Universitatis Agriculturae et Silviculturae Mendelianae Brunensis, 66(3): 669-675.

Fin condition was assessed in the rainbow trout (Oncorhynchus mykiss) at an experimental recirculating facility using manual feeding 2 and 3 meals per day. Fin Index (FI) was used as an indicator of the find condition. Comparing the feeding frequencies 2 and 3 meals per day, a statistically significant difference was found ( $p<0.05)$ for the FI of the pectoral, pelvic, anal, and caudal fins. For the 3 meals per day feeding frequency, a greater decrease of the FI was found compared to the feeding frequency 2 meals per day. In both pelvic fins the FI decreased by $53 \%$, in the caudal fins the FI decreased by $18 \%$ and by $11 \%$ in the anal fins, in the left pectoral fin the FI decreased by $6 \%$ and by $12 \%$ in the right one. Statistically significant difference was found between both pectoral fins for the feeding frequency of 3 meals per day. The left pectoral fin showed a FI higher by $8 \%$ compared to the right one; the reason for the asymmetry being the water flow direction in the circular tanks. It follows from the results that in terms of fish welfare, it is more advisable to administer the feed 2 meals per day at maximum, in order to lower the risk of random biting by other individuals and to obtain a better fin condition.
\end{abstract}

Keywords: rainbow trout, welfare, feeding frequency, re-circulated water, fin erosion

\section{INTRODUCTION}

At present, salmonid fish are farmed intensively at various specialized facilities, such as cage, flow-through or recirculating ones (Timmons and Ebeling, 2013). At such facilities the welfare could be decreased of farmed fish (North et al., 2006) for the purpose of obtaining higher increment, better feed conversion, and resistance to disease (Boujard et al., 2002, Suomalainen et al., 2005). The term welfare means freeing farmed animals from pain, fear, and hunger, and allowing them social behavior (Branson, 2008). In aquaculture, it also means maintaining favorable environmental conditions, optimum nutrition and system of breeding. Fin condition may serve as one of the indicators of the state of welfare (North et al., 2006, Rasmusen et al., 2007, d'Orbcastel et al., 2009). Impaired fish welfare manifests itself in the fins by their smaller size, frayed rays, occurrence of lesions and necrosis (Turnbull et al., 1998, Latremouille, 2003). These signs on fins can be found only in fish farmed at specialized fish farming facilities (Bosakowski and Wagner, 1994), they do not commonly occur in natural conditions (Stejskal et al., 2011). Possible causes of fin erosion are scraping against the tank surface, physical contact among fish, especially during feeding (Adams et al., 2007, Turnbull et al., 2008), unsuitable diet composition and management of feeding (Latremouille, 2003), manipulation of fish during sorting (Person-Le Ruyet et al., 2007) and bacterial infections (Ellis et al., 
2002). Fin condition is also affected by the stock density, water quality (Person-Le Ruyet et al., 2008), and type of breeding facility (Moring, 1982).

Fin condition can be affected in a major way by the management of feeding. Manual feed administration increases aggression in fish which results in random biting among individuals (Branson, 2008). Aggressive behavior can be decreased by continual feed administration using self-feeding systems (Suzuki et al. 2008, Person-Le Ruyet and Le Bayon, 2009) or by feeding ad libitum (Latremouille, 2003, Suzuki et al., 2008). When feeding manually, Rasmussen et al. (2007) and Suzuki et al. (2008) recommend administering the feed once rather than several times a day; the reason being the decreased risk of random biting from other individuals.

In spite of all the recommendations, fin erosion may not be completely eliminated (Latremouille, 2003). The fins most at risk are the dorsal and pectoral fins in salmonids (Turnbull et al., 1998) followed by the anal, caudal, and pelvic fins (Bosakowski and Wagner, 1994). The most frequently used method of evaluating the fin condition is the Fin Index (FI) or the fin length relative to the body length. In a natural population of rainbow trout (Oncorhynchus mykiss) with undamaged fins, isometric relationship was found between the body length and the FI for the pectoral, pelvic and anal fins. In contrast, negatively allometric relationship was found for the dorsal and caudal fins (Ellis et al., 2009). The fin condition of live fish may also be a decisive factor of their salability to end costumers (Hoyle et al., 2007, Stejskal et al., 2011) and provide information on the farming conditions (Klíma et al., 2013a).

The aim of the study was to evaluate the effect of feeding frequency on the fin condition in rainbow trout at an experimental recirculation facility under standard farming conditions.

\section{MATERIALS AND METHODS}

The effects of feeding frequency on the fin condition were studied at an experimental recirculation facility of the Fisheries and Hydrobiology Department of the Mendel University in Brno. Monosex, all-female population of the rainbow trout was selected, originating from the recirculation facility Dolní Babákov in the Czech Republic. The fish were left to acclimate for 10 days in a water-trough of a volume of $1.15 \mathrm{~m}^{3}$ at the amount of 4000 pcs of a size of $50-75 \mathrm{~mm}$ total length and of a weight of 2-4 g. The total stock weight was $12 \mathrm{~kg}$. The feeding frequency before start of experiment was 2 meals per day. Twenty pcs were taken from this tank for the assessment of the fin condition to establish the initial level condition. Subsequently, 599 pcs of fish of a mean weight of $3.33 \mathrm{~g}$ were randomly selected and divided into two circular tanks of a volume of $1 \mathrm{~m}^{3}$. The tanks were connected to independent external filtration units Eheim Professional 3. The first tank was stocked with
316 pcs of a mean weight of $3.16 \mathrm{~g}$. The second tank was stocked with 283 pcs of a mean weight of $3.53 \mathrm{~g}$. The stock weight of both tanks was $1 \mathrm{~kg}$. The fish were fed manually 2 meals per day with the feed Biomar Inicio 917 of a $1.5 \mathrm{~mm}$ pellet size (Biomar, Denmark; 47\% proteins, $20 \%$ fat, 19\% nitrogen free extract, brutto energy $22.3 \mathrm{MJ} \mathrm{kg}^{-1}$ ). The total daily feeding ration was set at $1 \%$ of the stock weight, and divided into 2 rations per day. After 67 days, the fin condition in 20 pcs of fish from each tank was evaluated. Fish from both tanks were fished out and the stock was adjusted to 250 pcs per each tank. In the first tank with the stock weight of $6.9 \mathrm{~kg}$ and the mean individual weight of $27.5 \mathrm{~g}$, the fish were manually administered 3 meals per day the feed Biomar Inicio 918 (Biomar, Denmark; 46\% proteins, $23 \%$ fat, $16.9 \%$ nitrogen free extract, brutto energy 23.1 $\mathrm{MJ} \mathrm{kg}^{-1}$ ). In the second tank with the stock weight of $7 \mathrm{~kg}$ and the mean individual weight of 28.1 g, the fish were manually administered 3 meals per day the feed Aller Silver (Aller Aqua, Poland; $45 \%$ proteins, $20 \%$ fat, $16 \%$ nitrogen free extract, brutto energy $21.6 \mathrm{MJ} \mathrm{kg}^{-1}$ ). Both feeds had a pellet size of $2 \mathrm{~mm}$. The daily feeding ration was set at $3.48 \%$ of the stock weight for the feed Biomar Inicio 918, and at $2.9 \%$ for the feed Aller Silver. The tanks were connected to a redundant external filter Nexus 310. Change of water was once per hour. The experiment was terminated after 28 days and the fin condition in 20 pcs of fish from each tank was evaluated. Fish mortality during the all experiments was below $0.5 \%$.

Physical and chemical properties of water were measured at the experimental facility before each morning (8.00 h) and evening (16.00 h) feed administration. The $\mathrm{pH}$, dissolved oxygen concentration, and water temperature were determined directly in the tanks using the Hach HQ40d meter (Hach-Lange, Germany). Water samples for chemical analyses were taken into $50 \mathrm{ml}$ plastic sample containers each time from the outflow of the filtration device into the tanks. Chloride contents and ammonia-, nitrite- and nitrate-nitrogen values were determined using standard methods for surface water analysis (Apha, 1998). All photocolorimetric measurements were done by spectral photometer PhotoLab 6600 UV-VIS.

For the fin condition evaluation, the fish were sacrificed by stunning with a blow to the back of the head followed by spinal cord transection. The experiment was performed in compliance with Czech laws for the protection of animals against cruelty (Act No 246/1992 and amendments), as approved by the Ethics Committee of the Mendel University in Brno, Czech Republic. Standard body length (SL) and weight was determined in the fish. The fish fins were spread and white paper was put underneath. For fin photographs, the camera Canon EOS 450D was used with the objective lens Canon EF100/2.8 MACRO USM connected to the notebook Asus S96Jm. A tripod and a light tent with diffused light for eliminating reflections were 
used. Using the program Digital Photo Professional (version 3.3.0.0), shots of the left, right lateral and pelvic perspective with a gauge were captured. Both pectoral and pelvic fins, dorsal, anal and caudal fins were evaluated. Photographs were processed and borderlines between the fins and the body were outlined using the program Paint.Net (version 3.5.11.). For fin length measurements, the program ImageJ, version 1.46r was used (Klíma et al., 2013b). From each fin, 3 lengths of fin rays were measured (right and left edge and the center of the fin). From these three values, the mean fin length was determined which was then used for the Fin Index formula. The results were processed and evaluated using the program Microsoft Office Excel 2007 and Statistica 12.

For fin condition comparison, Fin Index (Ellis et al., 2009) was used. It expresses the percentage of the mean fin length in relation to the standard body length of the fish. FI $=100 \times($ mean fin length/standard fish length). The feeding frequency was tested using $t$-test in the program Statistica 12 at a significance level of $p<0.05$. Initial level of Fin Index were for dorsal fins (11.2\%), caudal fins (14.3\%), anal fins (8.4\%), left pectoral fins (11.6\%), right pectoral fins (12.1\%), left pelvic fins (9.4\%), right pelvic fins (9.9\%).

\section{RESULTS}

During the whole experiment, values of ammonia and nitrites were elevated especially due to insufficient functioning of the filtration device (Tab. I). In order to eliminate their harmful effect on the fish, approximately half of the water in the system was regularly exchanged and the level of chloride concentration was replenished (addition of $\mathrm{NaCl}$ ). The mean SL of the observed fish ranged between $85-150 \mathrm{~mm}$, with the weight ranging between 11-65 g (Tab. II). In both tanks where feed was administered 2 meals per day, a statistically significant difference $(p<0.05)$ was found for the size and weight of fish. When comparing the FI of all fins, however, no statistically significant difference was found between these tanks. In the tanks where feed was administered 3 meals per day, no statistically significant difference was found either for the fish size, weight or FI (Tab. II). In the overall comparison of tanks where feed was administered twice daily and three times daily, a statistically significant difference $(p<0.05)$ was found for the size and weight of fish due to observing the FI during the growth of fish.

The total feed consumption by the stock and the evaluation of the feeding strategy using

I: Mean values \pm standard deviation of the physicochemical properties of water in tanks during the experiment.

\begin{tabular}{|c|c|c|c|c|c|c|c|c|}
\hline $\begin{array}{l}\text { Feeding } \\
\text { frequency }\end{array}$ & Tank & $\begin{array}{c}\text { Water temp. } \\
\left({ }^{\circ} \mathrm{C}\right)\end{array}$ & pH & O2 (\%) & $\begin{array}{l}\mathrm{N}-\mathrm{NH}_{4}^{+} \\
\left(\mathrm{mg} . \mathrm{l}^{-1}\right)\end{array}$ & $\begin{array}{l}\mathrm{N}-\mathrm{NO}_{2}^{-} \\
\left(\mathrm{mg} . \mathrm{l}^{-1}\right)\end{array}$ & $\begin{array}{l}\mathrm{N}-\mathrm{NO}_{3}^{-} \\
\left(\mathrm{mg} . \mathrm{l}^{-1}\right)\end{array}$ & $\underset{\left(\mathrm{mg} . \mathrm{l}^{-1}\right)}{\mathrm{Cl}^{-}}$ \\
\hline \multirow[t]{2}{*}{$\times 2$} & 1 & $17.0 \pm 1.0$ & $8.5 \pm 0.4$ & $89.2 \pm 10.5$ & $1.3 \pm 2.3$ & $1.3 \pm 1.4$ & $13.5 \pm 7.9$ & $76.7 \pm 27.5$ \\
\hline & 2 & $17.0 \pm 1.0$ & $8.5 \pm 0.4$ & $91.3 \pm 7.6$ & $1.3 \pm 1.4$ & $2.6 \pm 2.3$ & $11.4 \pm 8.6$ & $74.9 \pm 29.7$ \\
\hline \multirow[t]{2}{*}{$\times 3$} & 3 & $17.6 \pm 1.1$ & $7.8 \pm 0.4$ & $68.8 \pm 9.5$ & $1.5 \pm 1.2$ & $2.7 \pm 1.5$ & $47.4 \pm 17.2$ & $97.5 \pm 7.5$ \\
\hline & 4 & $17.6 \pm 1.1$ & $7.8 \pm 0.4$ & $71.8 \pm 6.5$ & $1.5 \pm 1.5$ & $1.0 \pm 1.4$ & $53.7 \pm 11.0$ & $100.6 \pm 8.8$ \\
\hline
\end{tabular}

II: Standard length $(S L)$ and weight of fish $(n=20)$ used for the fin condition evaluation. *denotes a statistically significant difference $(p<0.05)$ between tanks 1 and 2 .

\begin{tabular}{cccc} 
Feeding frequency & Tank & Standard length $(\mathbf{m m})$ & Weight $(\mathbf{g})$ \\
\hline$\times 2$ & 1 & $85.95 \pm 15.6$ & $11.59 \pm 6.6$ \\
$\times 3$ & 2 & $101.50 \pm 5.8^{*}$ & $18.62 \pm 8.7^{*}$ \\
& 3 & $148.55 \pm 9.2$ & $65.00 \pm 14.8$ \\
& 4 & $150.50 \pm 10.5$ & $64.15 \pm 13.2$ \\
\hline
\end{tabular}

III: The amount of consumed feed and the mean fish increment compared to the indices of production efficacy of feeds.

\begin{tabular}{cccccc}
$\begin{array}{c}\text { Feeding } \\
\text { frequency }\end{array}$ & Tank & $\begin{array}{c}\text { Amount of feed } \\
(\mathbf{k g})\end{array}$ & $\begin{array}{c}\text { Mean increment } \\
\text { per piece (g) }\end{array}$ & FCR & SGR \\
\hline$\times 2$ & 1 & 2.96 & 11.75 & 0.80 & 2.35 \\
& 2 & 3.03 & 13.52 & 0.79 & 2.39 \\
& 3 & 10.04 & 44.64 & 0.94 & 3.50 \\
& 4 & 7.51 & 34.96 & 0.86 & 3.03 \\
\hline
\end{tabular}


the production indices (FCR and SGR) are presented in Tab. III. Comparing the feeding frequencies of 2 and 3 meals per day, a statistically significant difference was found for the FI in the pectoral, pelvic, anal, and caudal fins (Fig. 1). When feed was administered 3 meals per day, a greater decrease of the FI was found compared to the feeding frequency 2 meals per day. In both pelvic fins the FI decreased by $53 \%$, in caudal fins the FI decreased by $18 \%$, and in anal fins by $11 \%$. In pectoral fins the FI was also found to be decreased when feed was administered 3 meals per day. In the left pectoral fin the FI decreased by $6 \%$; in the right one by $12 \%$. No statistically significant difference was found for the effect of feeding frequency on the dorsal fins. Comparing the tanks with the feeding frequency 3 meals per day, a statistically significant difference was found for the pectoral fins; other fins did not show statistically significant differences. The left pectoral fin showed a FI higher by $8 \%$ compared to the right one (Fig. 1). In contrast, when feed was administered twice daily, no statistically significant difference was found for the pectoral fins (Fig. 1) or for any other fins between the two tanks.

\section{DISCUSSION}

The effect of feeding frequency was observed during the growth of fish of the same origin, therefore the size and weight of fish was lesser when feed was administered 2 compared 3 meals per day. Different sizes of fish do not prevent from comparing the FI when evaluating the feeding frequency, as shown in tanks with the feed administered twice daily, where a statistically significant difference was found between the length and weight of fish but no statistically significant difference was found for the FI in all fins. These results are in accordance with the observations of Ellis et al. (2009) who found an isometric relationship between the body length and the FI for the pectoral, anal and pelvic fins. Contrarily, for the caudal fin they found a negatively allometric relationship between the FI and the body length which means that the FI gradually decreases with the growth of fish. A marked decrease of FI and a highly significant difference between the feeding frequencies means a frequent random fin erosion.

The dorsal fin was strongly eroded in all fish even before the initiation of the trial; under the conditions of the experimental facility, the fish were unable to regenerate their dorsal fins and therefore, no statistically significant difference was found between the individual feeding frequencies. Dorsal fin erosion occurred in fish after acclimation in the trough at a stock of 3478 pcs.m-3. Although the stock weight was only $9.6 \mathrm{~kg} \cdot \mathrm{m}^{-3}$, a marked dorsal fin erosion occurred probably due to the small tank volume. According to the observations of Wagner et al. (1996a), North et al. (2006) and Person-Le Ruyet et al. (2008), the stock density affects the dorsal fin condition and the FI.
North et al. (2006) observed a lower FI of the dorsal fin at a stock over $36.6 \mathrm{~kg} \cdot \mathrm{m}^{-3}$. Stock density in the tank is an important factor affecting the size of individual space among fish and the connected higher risk of collision among fish at feeding and erosion to fins (Person-Le Ruyet et al., 2007, Ellis et al., 2002). This is also connected to the tank volume where fish are kept. For the breeding of rainbow trout up to the age of a yearling, tanks of a volume of $3-8 \mathrm{~m}^{3}$ are recommended (Kouřil et al. 2008).

We found a higher FI in the pectoral, pelvic, anal and caudal fins when feed was administered 2 meals per day than when it was administered 3 meals per day, i.e. we achieved a better fin condition by feeding 2 than 3 meals per day. Similar findings were reported by Rasmussen et al. (2007) for the left pectoral fin which was in a better condition when fish were fed 1 meals per day than when they were fed 3 meals per day. They explain it by the position of fins close to the fish jaw where there is a higher risk of biting from other individuals. In other fins they did not observe a marked aggravation of their condition. According to Branson (2008), the aggression of fish increases when they are fed manually and random fin erosion occurs during feeding. For decreasing the aggression, Suzuki et al. (2008) recommend shortening the time without feed intake by a more frequent feed administration during the day, ideally by using self-feeding systems. Self-feeding systems are recommended for improving the find condition also by other authors, e.g. Wagner et al. (1996b), Person-Le Ruyet and Le Bayon (2009). Self-feeding systems provide feed according to the fish's needs, feeding the fish until satiation; they decrease stress and aggressive behavior, and improve welfare (Branson, 2008). Latremouille (2003) recommends feeding fish until satiation because it reduces aggressive behavior and biting from other individuals and the occurrence of fin erosion, however, fin erosion is not completely eliminated. Rasmussen et al. (2007) and Suzuki et al. (2008) also recommend feeding fish until satiation but only once a day.

The greatest effect of our experiment was observed in the pelvic fins, followed by the caudal, anal, and pectoral fins. This finding is in contrast with the observations of other authors, where the fins reported most at risk are the dorsal and pectoral fins (Turnbull et al., 1998; Rasmussen et al., 2007) followed by the anal, caudal and pelvic fins (Bosakowski and Wagner, 1994). Considering the fact that the dorsal fin was strongly erosion from the start of the trial, the effect of feeding frequency on the dorsal fin could not be established. Another factor influencing the fin condition is the breeding system design; pectoral fins especially are erosion by scraping against the tank surface (Turnbull et al., 1998). Person-Le Ruyet et al. (2008) determined the effect of water quality on the condition of the pectoral and dorsal fins, with both fins showing a better condition at a low stock density (up to $25 \mathrm{~kg} \cdot \mathrm{m}^{-3}$ ), a dissolved oxygen concentration of $6 \mathrm{mg}^{-1}$ at the outflow, and a total ammonia nitrogen (TAN) of $0.6 \mathrm{mg} \cdot \mathrm{l}^{-1}$. 

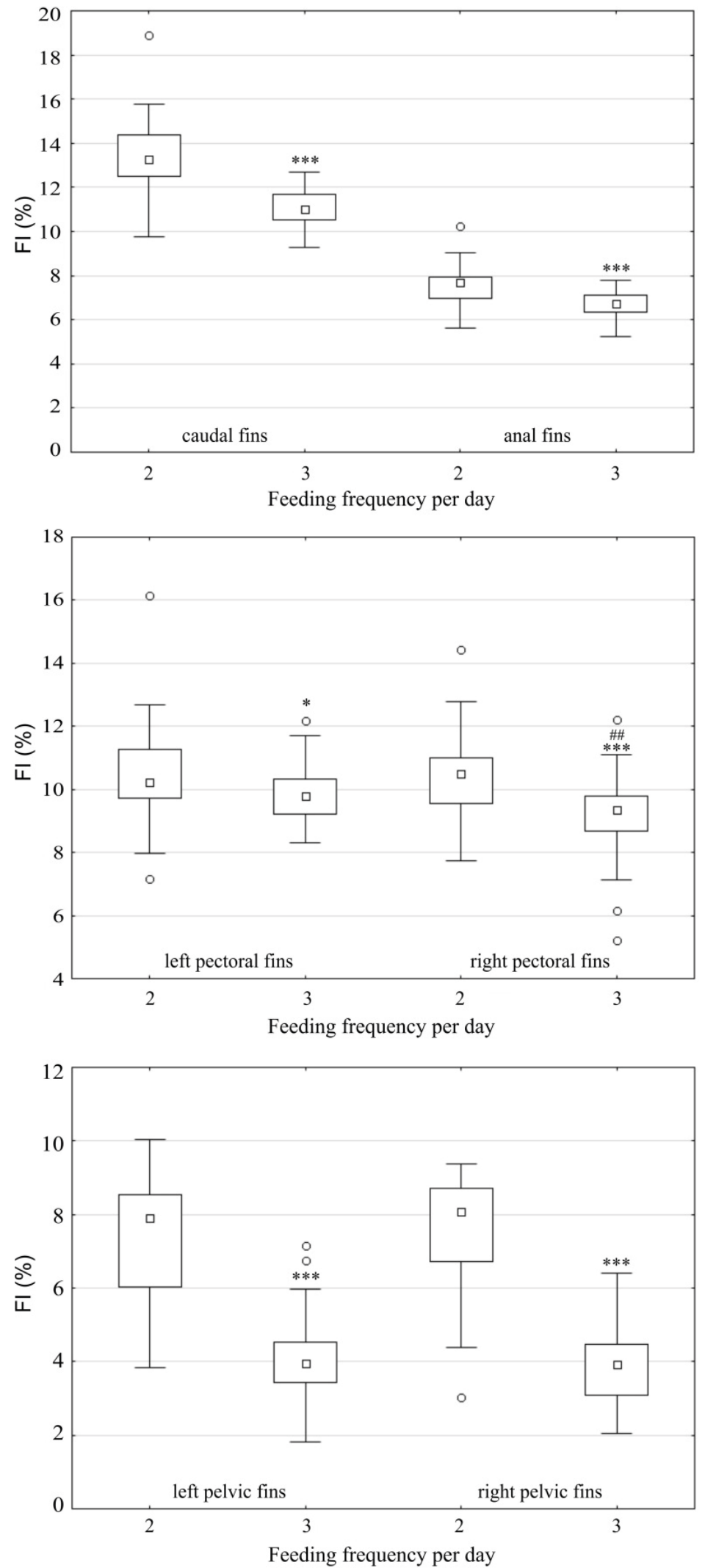

1: The effect of feeding frequency on the FI of fins in the rainbow trout. C - caudal fins, A - anal fins, LP-left pectoral fins, PP - right pectoral fins, $L V$ - left pelvic fins, $P V$ - right pelvic fins. The number denotes the feeding frequency, * denotes a statistically significant difference $\left(* * * p<0.001,{ }^{*} p<0.05\right)$ between fins of fish with different feeding frequencies. \# denotes a statistically significant difference (\#\# $p<0.01$ ) between pectoral fins under the same feeding frequency 
According to Fawc (1996), incorrect manipulation with fish also influences the fin condition. Erosion fins can be subsequently colonized by bacteria such as Aeromonas, Pseudomonas, Vibrio, Dermocystidium, Flexibacter and give rise to lesions (Schneider and Nicholson, 1980; Latremouille, 2003). In order to decrease the degree of these effects on fish, it is necessary to optimize the breeding conditions and the breeding system. However, according to the observations of Latremouille (2003), even in spite of all efforts the ideal fin condition may not be achieved. A certain degree of fin erosion is to be expected in the RAS systems even under optimum breeding conditions.

The left pectoral fin showed a higher FI and better condition than the right one at the feeding frequency 3 meals per day. This is in agreement with the observations of Rasmussen et al. (2007) who found a better condition in the left pectoral fin compared to the right one. In circular tanks, asymmetrical erosion to pectoral fins occurs (Branson, 2008). A possible explanation is the flow direction in circular tanks where in the counter-clockwise flowing the left fin is closer to the center of the tank and when feed is administered to the center of the tank, there is probably a higher risk of random biting into the left fin which is closer to the center. The fin size is also influenced by the flow rate in tanks, with the pectoral and dorsal fins showing smaller length in recirculating systems compared to flow-through systems (D'orbcastel et al., 2009).

\section{CONCLUSION}

Feeding frequency affects the condition of pelvic, caudal, anal, and pectoral fins. A higher FI and better fin condition were observed when feed was administered 2 meals per day compared to feeding 3 meals per day. The reason is reducing the frequency of random fin biting from other individuals during the feeding. The dorsal fin showed strong erosion from the beginning of the trial, therefore, the effect of feeding frequency on this fin could not be evaluated. When feeding 3 meals per day, asymmetry was found in the pectoral fins, with the left pectoral fin showing a higher Fi and better condition. In circular tanks, pectoral fin erosion is affected by the flow direction. In the counter-clockwise flowing, the right pectoral fins of fish are closer to the center of the tank where there is a higher risk of random biting from other individuals during the feeding. Based on our findings, it is advisable to feed fish twice a day at maximum, or as per the recommendations of other authors, to feed fish once a day until satiation, or to use self-feeding systems in order to improve the find condition in the bred rainbow trout. Better fish welfare should also manifest itself in a better condition (increment) and higher survival of fish.

Acknowledgment

This study was supported by the National Agency for Agricultural Research (grant No. QJ1510077).

\section{REFERENCES}

ADAMS, C. E., TURNBULL, J. F., BELL, A., BRON, J. E. and HUNTINGFORD, F. A. 2007. Multiple determinants of welfare in farmed fish: stocking density, disturbance, and aggression in Atlantic salmon (Salmo salar). Can J. Fish Aquat. Sci., 64(2): 336-344.

APHA, 1998. Standard methods for the examination of water and wastewater. Washington D.C.: American Public Health Association Inc.

BOSAKOWSKI, T. and WAGNER, E. J. 1994. Assessment of Fin Erosion by Comparison of Relative Fin Length in Hatchery and Wild Trout in Utah. Can. J. Fish. Aquat. Sci., 51: 636-641.

BOUJARD, T., LABBÉ, L. and AUPÉRIN, B. 2002. Feeding behaviour, energy expenditure and growth of rainbow trout in relation to stocking density and food accessibility. Aquac. Res., 33(15): 1233-1242.

BRANSON, E. J., 2008. Fish welfare. London: Blackwell Publishing Ltd.

D'ORBCASTEL, E. R., RUYET, J. P.L., LE BAYON, N. and BLANCHETON, J. P. 2009. Comparative growth and welfare in rainbow trout reared in recirculating and flow through rearing systems. Aquacult. Eng., 40: 79-86.

ELLIS, T., HOYLE, I., OIDTMANN, B., TURNBULL, J. F., JACKLIN, T. E. and KNOWLES, T. G. 2009. Further development of the "Fin Index" method for quantifying fin erosion in rainbow trout. Aquaculture, 289(3-4): 283-288.

ELLIS, T., NORTH, B., SCOTT, A. P., BROMAGE, N. R., PORTER, M. and GADD, D. 2002. Review Paper. The relationships between stocking density and welfare in farmed rainbow trout. J. Fish Biol., 61(3): 493-531.

FAWC, 1996. Report on the Welfare of Farmed Fish. [Online]. Available at: http://www.fawc.org.uk/reports.htm [Accessed: 2013-05-31].

HOYLE, I., OIDTMANN, B., ELLIS, T., TURNBULL, J., NORTH, B., NIKOLAIDIS, J. and KNOWLES, T. G. 2007. A validated macroscopic key to assess fin damage in farmed rainbow trout (Oncorhynchus mykiss). Aquaculture, 270(1-4): 142-148. 
KLÍMA, O., KOHÚT, L. and MAREŠ, J. 2016. Condition of the dorsal fin of rainbow trout during the growth in special fish culture facilities. In: VOSLÁŘOVÁ, E. (Ed.). Animal protection and welfare 2016 - 23 rd International Conference. University of Veterinary and Pharmaceutical Sciences Brno, Czech Republic, pp. 48-56.

KLÍMA, O., KOPP, R., HADAŠOVA, L. and MAREŠ, J. 2013a. Fin condition of fish kept in aquacultural systems. Acta Univ. Agric. Silvic. Mendelianae Brun., 61(6): 1907-1916.

KLÍMA, O., RYBNIKÁR, J. and MAREŠ, J. 2013b. Comparison of two methods of image analysis for the evaluation of surface fin. In: ŠKARPA, P., RYANT, P.,CERKAL, R., POLÁK, O., KOVĂRNÍK, J. (Eds.). MendelNet 2013 - Proceedings of International PhD Students Conference. $1^{\text {st }}$ Edition. Faculty of Agronomy: Mendel University in Brno, Czech Republic, pp. 748-752.

KOUŘIL, J., MAREŠ, J., POKORNÝ, J., ADÁMEK, Z., RANDÁK, T., KOLÁŘOVÁ, J., and PALÍKOVÁ, M. 2008. Breeding of salmonids fish, grayling and whitefish. University of South Bohemia in České Budějovice and Research Institute of Fish Culture and Hydrobiology in Vodňany.

TIMMONS, M. B. and EBELING, J. M. 2013. Recirculating Aquaculture, $3^{\text {rd }}$ Edition. Ithaca, NY: Ithaca Publishing Company.

LATREMOUILLE D. N. 2003. Fin Erosion in Aquaculture and Natural Environments. Rev. Fish. Sci., 11(4):315-335.

MORING, J. R., 1982. Fin erosion and culture-related injuries of Chinook salmon raised in floating net pens. Prog. Fish. Cult. 44(4): 189-191.

NORTH, B. P., TURNBULL, J. F., ELLIS, T., PORTER, M. J., MIGAUD, H., BRON, J. and BROMAGE, N. R. 2006. The impact of stocking density on the welfare of rainbow trout (Oncorhynchus mykiss). Aquaculture, 255(1-4): 466-479.

PERSON-LE RUYET, J. and LE BAYON, N. 2009. Effects of temperature, stocking density and farming conditions on fin damage in European sea bass (Dicentrarchus labrax). Aquat. Living Resour., 22: 349-362.

PERSON-LE RUYET, J., LABBÉ, L., LE BAYON, N., SÉVÈRE, A., LE ROUX, A., LE DELLIOU, H., and QUÉMÉNER, L. 2008. Combined effects of water quality and stocking density on welfare and growth of rainbow trout (Oncorhynchus mykiss). Aquat. Living Resour., 21: 185-195.

PERSON-LE RUYET, J., LE BAYON, N. and GROS, S. 2007. How to assess fin damage in rainbow trout, Oncorhynchus mykiss? Aquat. Living Resour., 20: 191-195.

PURSER, J. and HART, P. 1991. Effect of stocking density on the growth of juvenile rainbow trout. Aquaculture, 5: 46-48.

RASMUSSEN, R. S., LARSEN, F. H. and JENSEN, S. 2007. Fin condition and growth among rainbow trout reared at different sizes, densities and feeding frequencies in high-temperature re-circulated water. Aquacult.Int., 15(2): 97-107.

SCHNEIDER, R. and NICHOLSON, B. L. 1980. Bacteria associated with fin rot disease in hatchery-reared Atlantic salmon (Salmo salar L.). Can. J. Fish. Aquat. Sci., 37: 1505-1513.

STEJSKAL, V., POLICAR, T., KŘIŠŤAN, J., KOUŘIL, J. and HAMÁČKOVÁ, J. 2011. Fin condition in intensively cultured Eurasian perch (Perca fluviatilis L.). Folia Zool., 60: 122-128.

SUOMALAINEN, L-R., TIIROLA, M. A. and VALTONEN, E. T. 2005. Influence of rearing conditions on Flavobacterium columnare infection of rainbow trout, Oncorhynchus mykiss (Walbaum). J. Fish Dis., 28(5): 271-277.

SUZUKI, K., MIZUSAWA, K., NOBLE, C. and TABATA, M. 2008. The growth, feed conversion ratio and fin damage of rainbow trout Oncorhynchus mykiss under self-feeding and hand-feeding regres. Fisheries Sci., 74: 941-943.

TURNBULL, F. J., ADAMS, E. C., RICHARDS, H. R. and ROBERTSON, A. D. 1998. Attack site and resultant damage during aggressive encounters in Atlantic salmon (Salmo salar L.) parr. Aquaculture, 159: 345-353.

TURNBULL,J.F., NORTH, B.P., ELLIS, T., ADAMS, C.E., BRON, J., MACINTYRE, C.M. andHUNTINGFORD, F. A. 2008. Stocking Density and the Welfare of Farmed Salmonids, In: BRANSON, E. J. (Ed.). Fish Welfare. Oxford, UK: Blackwell Publishing Ltd, pp. 111-120.

WAGNER, E. J., INTELMANN, S. S. and ROUTLEDGE, M. D. 1996a. The Effects of Fry Rearing Density on Hatchery Performance, Fin Condition, and Agonistic Behavior of Rainbow Trout Oncorhynchus mykiss Fry. J. World Aquacult. Soc., 27: 264-274.

WAGNER, E. J., ROUTLEDGE, M. D. and INTELMANN, S. S. 1996b. Assessment of Demand Feeder Spacing on Hatchery Performance, Fin Condition, and Size Variation of Rainbow Trout Oncorhynchus mykiss. J. World Aquacult. Soc., 27: 130-136. 